\title{
Positive and Negative Factors Involved in the Development of Creativity in Children
}

\author{
Bedri Karayağmurlar \\ Dokuz Eylül University, Turkey \\ karayagmurlar@gmail.com
}

\author{
Firdevs Sağlam \\ Dokuz Eylül University, Turkey \\ sfirdevs@hotmail.com
}

\begin{abstract}
Communities make plans about situations which are likely to be in the future and they try to continue their existences in accordance with these plans. But some communities can not keep up with this cycle and they are separated from the others and are marginalized and then they are doomed to extinction or exploitation. To avoid it, a structure that is open to developments and adapts them is necessary. The most important condition of that is a creative individual. These individuals improve societies by protecting them from extinction or exploitation. Creativity provides facilities in all areas of life for people and helps to be individual compatible with changing and developing world. This situation plays a significant role not only in the community but also individual's life and in coping with many evets faced. Everything which prevents the development of creativity should be detected and eliminated when we think about the importance of creativity. In this study, what is creativity, the importance of creativity, positive and negative factors affecting creativity and the importance of art education in creativity have been examined and datum obtained from them have been interpreted.
\end{abstract}

Keywords: Creativity, Art education, Child 


\section{Introduction}

In today's world, because technology constantly evolves, many innovations and conveniences are in human life. Individuals are expected rapidly adapting to progressing, evolving and changing world. "In societies, undoubtedly one condition of adapting social change, renewal, dynamism and waves of change is that individuals with innovative and creative approach are developed and trained. Eliminating the items which prevent it is basis of modernization" (Artut, 2004, p. 51). Almost all contemporary societies are built on this understanding. The most basic way to accomplish it is education. Policies about the creation of innovative and creative individuals through education provide both individuals and the society with being effective in the world. So creativity is important. Acording to Sünbül (2013), there are different opinions about creativity. The first of them is that the absolute creativity and the criteria of creativity can't be... In a second opinion is that creativity criteria can vary from culture to culture throughout history... The third view is that creativity requires preparation... According to another opinion, creating is activity that directs creativity and has grades in it (p. 82-83). Because of being of different opinions on creativity, we can infer this concept is very versatile and needs to be discussed.

\section{What is Creativity?}

In society, Creativity is known as the activities that people make in only certain areas. But this is a very limited idea for the concept of creativity. It can be defined as the individual turns his thinking process into a solution oriented activity in a difficult situation, in a matter to be resolved, in the completion of the deficiency etc... . It is a kind of knowing and finding activity. We can see many definitions about creativity. these are "a state of mind in which all our intelligences are working together" (Lucas, 2001, p. 38) ; "the ability to solve problems and fashion products and to raise new questions" (Gardner, 1993, p. 48); "getting away from the main track, breaking out of the mold, being open to experience, and permitting one thing to lead to 
another" (Bartlett, 1958, p.103). These definitions show us creativity is a very crucial and special characteristic in human life. Creativity is a phenomenon that might help us not only in particular issues but also in every area of life. In other words it is a kind of behavior that helps individuals in adapting to new forms, in converting life to a regular structure, in coping with difficult situations.

Creativity is a human characteristic like thinking. Creativity consists of actions that are related to consciousness, thought, forming and imagination. Creativity that means breeding, forming and producing can appear in different ways. It shows itself in all areas of life, in original manner, in finding new solutions for problems. It is defined as the ability that is displaying reveal new experiences, new thoughts (ideas) and new products in new thinking scheme by establishing relationships that previously haven't been established (Karayağmurlar, 1993, p. 384).

Creativity ensures to prevent unwanted situations, it as well as offering individual good features. When Individual recognizes and develops his creativity, he gains self-confidence, and conducts his life in the desired direction. "Creativity requires an ability to integrate and synthesize relevant information from across disparate subject areas and combine it in novel ways. It is also requires high levels of personal motivation, interest and persistence, as well as a willingness to take risks, even in the face of doubt" (Ruppert, 2010, p. 1). The experiences shape people's life. Conducting situations in these experiences by using their creativity provide understanding changes and developments in today's world and adapting them for people.

\section{Positive and Negative Factors in the Development of Creativity}

Societies that mostly consist of the creative people constanly evolve and have a substantial impact on future generations to be more healthy and beneficial. So factors that hinder the development of creativity should be abolished and everything that improves creativity should be done. Each individual maynot be creative in same areas. But it doesn't change the truth of that everyone is creative. It is important to ensure awareness of creativity and to develope this feature. Exposing and improving this feature shoul be supply especially at early childhood. 
As child grows, he is getting better at adding things which he knows to things which he sees and things he sees to things he knows. Meanings of the things he faced are varied in time and each past experience is seen to play role in this. Child is getting better at understanding of something what is and how is useful and because of that, he requires more and more prior knowledge and tips (Buyurgan and Buyurgan, 2007, p. 34-35).

Child obtains the prior knowledge through different units in their living area and their senses. He can make them himself without help; but it means a waste of time for him .Child's development -this can be his own country or the other country- should be performed in a specific order to improve equally with his peer.

Because Children spend usually time with their family, school, and environment, these structures are very important. Their behaviors comprise and develop with this triangle. Children provide personal and spiritual formation with things seen and gained from these structures. Due to different reasons, especially school is at the center of the child's life after a certain period. It is understood creativity improve more easily through education when it is thought that the formation of behavior is easier with education.

\footnotetext{
People can not be trained by suppressing their characteristics. Because of that, courage and freedom that are necessary for the emergence of creativity shouldn't be prevented. We can see individuals equipped with knowledge and skills, but he can not feel free, creative while showing courage; timid, shy, also careless, frivolous creative types can be still seen. Creativity isn't a human characteristic that can be measured by tests. Creativity is known with the works to be done by observing relationship with the abilities interests, size, in a long process of education (Karayağmurlar, 1993, p. 384-385).
}

Not only shouldn't child be so much free but also he shouldn't be left under strict rules. Creating environment that he can express himself freely is important. Despite of deficiencies related to schools, being a lot of students in clasrooms in Turkey, educators firstly should 
recognize each individual and be aware of his interest and ability. When they know their students charecteristics it can be found different opinions about how to improve creativity. Teachers have an important role in this issue. To do this task, all teachers should know how much important is creativity in education. Teachers who know that can help to their students and can plan curriculum. Sak (2011) says Creativity is an ability which is innate and special to humans among living things; Even if development of creativity ability is prevented for several reasons, development of creative ability, life experiences can be regained, stimulated and developed with special programs (p. 10).

\begin{abstract}
At the beginning of factors that inhibit creativity is conformism. This concept known as "Conformism" in Western languages, the meaning to fit a specific format (conforma-Latin) and social situation emerges and is conform to the format.In the community and society, an individual who is fit to impose itself to the rules, etiquette and courtesy, fashion appropriate to feel the obligation to comply with such cases is called as conformism. Individuals not wanting to attain " other " to be a refusal for gaining a certain position (status) against a number the society of judgement, Although it is not compulsory not facing up to any sanction to be another and another to act (fashion, clothing, behavior, attitude), in fact, at least to a certain extent to get rid of mold or change them block creativity waiting courage (Sak, 2011, p. 10)".
\end{abstract}

Social norms, traditions, customs and spiritual values are necessary for the protection of society. However, these structures that connect people to each other and are identical lifestyle may hinder individuals because of their teachings. These values should not be an obstacle in child development. Each individual has different properties physically and spiritually. One type individual who has behaviors that are thought to be beneficial for society is wanted to create by changing individuals' different charecteristics. It means deteriorating the balance of the individual and conflicting with himself. People think that society excludes them when they don't obey the social rules. So, they try to keep within these rules. They are stuck between themself and the social rules and as a result they can be unhappy. Sak (2011) puts in 
order the factors that inhibit creativity these are lack of inner freedom; If working on what topic or area, that area and the lack of adequate information on the subject; Inability to secure from external conditions and external relations; of making mistakes, falling to defeat, fear of being ridiculed; a certain authority (such as the father's authority) is not dependent; excessive authority (perfectionist) not; All education and training from one system weighted in favor of reason and logic have passed (p. 11). Because people want society doesnt exclude them, they continuously control their behaviors and acts. People who come under pressure of both society and their thinking feel themselves in a bell glas and as a result they reach an impasse. In order to eliminate this problem, primarily individuals carefully are monitored and if there are such cases, it is required to find what the principal source is. With the data obtained, the path that will be followed should be determined by cooperating with the teacher.

The opinion that artistic creativity doesn't improve with learning can be considered among the factors that inhibit creativity. In this approach, two-way barrier is located; first, every child is creative. It need not be developed with the outside impact. Second, creativity is innate. Some children are programmed to be creative. Outside of these programs can not corrupt any effort. The creativity is blocked in both approaches the first idleness the other disbelief... Creativity doesn't develop in deep ignorance and fear or out of the inability of certain patterns even in the case.. Another of the important factors that inhibit creativity is excessive "perfectionism", a kind of work done in the inability to find sufficient competence and value. It is thinked that gender is sometimes prohibitive for creativity. For creativity inherently requires both freedom and sensibility. In an environment where it is thought Sensibility a property of feminine and freedom a property of masculine, fear of getting away from both sexes of their properties inhibit creativity (Kırışoğlu, 2002, p. 179).

There are some cliches about creativity. These cliches are being creative varies from woman to man and woman is more creative than man. They are prejudices. These prejudices cause the idea of that some things can be done only by a certain gender and so the other gender loses their self confidence, interest and expectation about doing some things. 


\begin{abstract}
The creativity of individual reveals and develops with asking questions relating to objects, evets and events in childhood and youth period, interacting their feelings and thoughts with the outside world... As "creative and non- creative" of Classification of people in their lives isn't suitable. Creative qualities in people have certain degrees their own. When appropriate conditions are created, we can see that some creative features of a lot of people emerge. Creative thinking is a feature that every normal person has. However, the degree-level emergence, continuity and development of creativity may vary from person to person by depending on the sociological circumstances (Artut, 2004, p. 52).
\end{abstract}

People have tried to know everyting since they were born. To understand or learn, people have great wonders and it is known as curiosity. If they aren't curious, they don't want to understand and to learn things in the world. Thanks to curiosity, human touches, looks, listens and asks questions, in other words, human tries to detect the world and nature. As in many things, curiosity has also an important role in mobilizing of creativity. "Children's curiosity, researching emotions being especially the starting point for creativity souldn't be dulled, approaches improving creativity thoughts, accumulation of knowledge, environment, shoul be offered them in education system. (Buyurgan and Buyurgan, 2007, p. 28) ". Creativity can emerge not only when the person is encouraged and is suitable conditions are provided but also it may be revealed in out of these conditions. If children who grow up a poor environment want, they can make their toys, musical instruments, or tools and goods being necessary for them with different materials. With this way, child can think he carries on his life by himself and trust himself. Creativity is important in terms of the development of social relationships. "Creativity is described as seeing and expressing new relationships. Therefore, creativity can occur in in thinking, in the forms of social interaction, in practice, in work and play” (Sünbül, 1950, p. 83). As expressed, creativity isn't observed only in certain areas and in certain circumstances. It occurs in circumstances which child needs and desires in every area of life. It is essential to create the necessary of social interaction of environment for child. 
Another inhibiting factor is that people who think only their thought or belief is right want the others must accept their thoughts.

"Because children are face to face with direction of art, anybody who is institution, trainer and parents shouldn't enter between them and shouldn't insist on the scale of values, beliefs, passions, patriotism etc... Otherwise primary aims that occur with arts education can't be actualized, puritan can be teached not free thought, as a result children find by themselves in a world which is there are sins, crimes, shames" (Erinç, 2004, p. 93). İndividual in this world has certain boundaries. Child who thinks is no good them aside reveal their properties, becomes unhappy.

\title{
Impacts of Arts Education for Creativity of Children's Paintings
}

\author{
Making a pictureis a iconic game for children. \\ The thing children revealing in this game \\ is images about their mental and emotional \\ life. They have a world there are joys, \\ sorrows, desires and contradictions
}

Art education is an area that improves individual's aesthetic views and teachs how feelings and thoughts can be transferred with art. With this training, individuals learn to think with images and also improve their visual perception. "Visual perception is the most effective skill in the other skills that are cognitive and emotional" (Gültekin, 2011, p. 5). When someone produces something with art, he reaches things that he need emotionally and he feels relieved. Art is thinking, assessment, in other words the solving the problem. This is made through visual thinking, line, color, and shaping rather than that it is done with numbers in mathematics. Artistic activities starting with the simple actions reaches more conscious level when age and perception of the level progress. Stages in child painting are a very good 
example to see 1t. Buyurgan and Buyurgan (2007) say that Child painting starting from scratch developing towards symbolic expression emerge after a series of actions such as seeing, sensing, image acquisition, storage, retrieval, thinking and connotation. Children tend to combine at an image being the separate elements of composed of broken fragments by basing on a random impression gained from objects in action of thinking (p. 34). When we make the curriculum of art education, we should pay attention to the child development stages. This is basic need to develop creativity

Child enters the creative process in art activities, could be called a kind of detection identification process. Within this process, the child removing or adding about thought things reaches new things as a result of this.

\footnotetext{
The creative process is not as a result of illness, it is discovered as emotional health depictions in the highest degree, an expression normal people performing themselves. Creativity is seen the artist as well as scientists, aesthetic as well as the thinker's labor and creativity of the range, the ola modern technology, the captain of the or a mother with a child of normal relations arise in you, drawn should be limited. Creativity is the making and process of entity revealing according to Webster (May, 2001, p. 63).
}

As in other areas also in the field of art education individuals realize their features with intellectual and physical movement performed there thanks to creativity and include it as a way of a continuity of life. With the emergence of individual creativity acts and using it increase his awareness about nature and about himself. "To be buried, to be absorbed, go caught completely immersed, etc... the state of the creative artist or scientist, or they use to describe children playing. Whatever name called unique creativity is characterized as an intense awareness, increase in awareness" (May, 2001, p. 66). Individuals who About the nature of the information they have, according to their perception of the world that combines a creative process produces new things from them in the meantime people entering creates 
new life. These experiences are fed with the values of art itself. Due to owned and given many positive features, aimed at the educational process improving creativity needs to be planned. "Whatever art education is thought for which level, primarily: 1- personality characteristics of individuals in the group 2 - recognition of the creative process (This step consists of theoretical and practical studies) 3 - At the end of this period, the evaluation of emerging forms of work must be programmed and implemented" (Karayağmurlar, 1990, p. 208). It is fact that it is much more easy being gained the wanted behavior thanks to created an art education program with what is the creative process is known, child put in the center and the results of this process evaluated.

When we look at child painting, we see that child starts to scribble any place by taking a pen or something similar after a certain period. Basically painting or scribbling is a game for him rather than artistic movements and it is requirement for him. Children learn and detect many things in this game. His doodles and paintings within this game are supporting activities for learning process.

In the paintings of small children seen is not an abstraction. Their perception of the world depends on their image, are perceptual generalizations. Children progress themself as the rectilinear his physical, spiritual, mental, social development. If Perception becomes stronger and learning increases, the differences of their painting are felt. The drawing about the objects properties in their paintings develops (Buyurgan and Buyurgan, 2007, p. 35).

When child knows environment and nature, he turns his linear action to shapes that look like forms in nature. Perceived or thought things could return to us as a drawing or he can describe them without any purpose as well. Child paintings should not be compared with the artist's works or with painting drawed presence in nature the exact analogy and should not 
be expected to make similar works like artists' works. Child does not pursue any goals and interests in art activity. He is in it to play game or to express himself.

The first year's romantic approach of children's painting leaves consistently itself the opinions depending on observation and examination. In these paintings are searched especially the marks of creativity in addition to their rational, the spiritual development. This behavior is the most important factor in the child's own life and experiences. When children turn the experiences gained with the environment directly to a form of art as visual, their creativity progress (Buyurgan and Buyurgan, 2007, p. 36).

Child develops himself with art process in an intellectual way and this process can help him to succeed and to look at other activities that are in their life with conceptual approach. Paintings an activity made of various materials at the same time, he learns materials how to use and where to use. This using reflects to objects he uses in daily life. As a result he can create aesthetic environment.

\section{Conclusion}

Creativity is a phenomenon that affects people as very versatile. In recognition of this, and environmental relationships in the family and in school activities towards the development and promotion of this effort is required. Development of individuals and adapt to the environment in terms of social formation is a known fact that a great importance. This awareness not only among teachers, families, and society in people from other departments should be established and it should be emphasized as well. Individuals not only physically but also spiritually enters a development process. Creative individuals or develop this property province who pretends spiritual development of individuals in completing difficult. Many things using the creative property itself overcome all the difficulties that individuals feel more powerful and therefore the opposite of today's conditions become major factor in the 
formation of the desired structure of society. Society is forming units how well planned, organized or applied basic structure that brings benefits if desired.

Discovered and developed, especially in the field of art education creativity is valid in all areas of life and creates a larger domain. Visually -minded individuals entered the production process is versatile. In this process, individuals can not only produce effects at the same time getting rid of all external embarks on a journey in his inner world. By leaving aside their limits, they are free and feel relaxed. For all these reasons the development of creativity in the elimination of negative factors that contribute to the development of the child's creativity and a system must be created that will be. In this study, we focus on the positive and negative effect on creativity, a thorough understanding of the factors, to be followed in deciding on the road is considered to be an important guide.

\section{References}

Artut, K. (2004). Okul Öncesinde Resim Eğitimi. Ankara: Anı.

Bartlett, F. C. (1958). Thinking: An Experimental and Social Study. New York: Basic.

Buyurgan, S. \& Buyurgan U. (2007). Sanat Eğitimi ve Öğretimi. Ankara: Pegem A.

Erinç, S. M. (2004). Kültür Sanat Sanat Kültür. Ankara: Ütopya.

Gardner, H. (1994). Creating Minds: An Anatomy Of Creativity As Seen Through The Lives Of Freud, Einstein, Picasso, Stravinsky, Eliot, Graham and Gandhi. New York: Basic.

Gültekin, T. (2011). Sanat Eğitiminde Estetik Değerlerin Gelişimi Sürecinde Çocuk ve İletişim. Akademik Bakış Dergisi, 24, 1-14.

Kırışoğlu, O. T. (2002). Sanatta Eğitim Görmek Öğrenmek Yaratmak. Ankara: Pegem A Press.

Karayağmurlar, B. (1993). Yaratıcı Bireylerin Yetiştirilmesi Açısından Genel Eğitim İçinde Sanat Eğitiminin Yeri. Dokuz Eylül Üniversitesi, 1, 368-387. 
Karayağmurlar, B. (1990). Sanatta yaratıcılık ve eğitim. Yayınlanmamış Yüksek Lisans Tezi, Dokuz Eylül Üniversitesi, İzmir.

Lucas, B. (2001). 'Creative Teaching, Teaching Creativity and Creative Learning', in Craft, A., Jeffrey, B., \& Leibling, M. (Eds) (2001), Creativity in Education. London: Continuum

May, R. (2001). Yaratma Cesareti (A. Oysal, Çev.). İstanbul: Metis.

Ruppert, S. S. (2010). Creativity, Innovation and Arts Learning: Preparing All Students for Success in a Global Economy. Arts Education Partnership (NJ1).

Sak U., San, İ., Ören, M. Üstindağ \& the others (2011). Okulöncesinde Yaratıcılık. Eskişehir: Açık Öğretim Fakültesi.

Sünbül, A. M. (2000). Yaratıcılık ve Sinıfta Yaratıcılığın Geliştirilmesi. NE Ü. Ĕğitim Fakültesi Dergisi, 10, 82-94. 